\title{
Diverse foraging strategies in lactating New Zealand sea lions
}

\author{
B. Louise Chilvers ${ }^{1, *}$, Ian S. Wilkinson ${ }^{1,2}$ \\ ${ }^{1}$ Marine Conservation Unit, Department of Conservation, PO Box 10420, Wellington 6143, New Zealand \\ ${ }^{2}$ Department of Environment and Conservation, Locked Bag 914, Coffs Harbour, New South Wales 2450, Australia
}

\begin{abstract}
Diving and foraging behaviours of marine predators are thought to be coupled with species demographics, with benthic foraging species found to have small population sizes and low growth rates. This was thought to be the case for New Zealand (NZ) sea lions Phocarctos hookeri, previously identified as solely benthic foragers with a small declining population. Female NZ sea lions dive deeper and for longer than any other otariids (eared seals). They exceed their calculated aerobic dive limits (CADL) during $68 \%$ of all dives, indicating that they are operating near their maximum physiological capacity. Recently, however, individual NZ sea lions have been found to have 2 distinct dive profile types or foraging patterns: a benthic diving profile and a deeper, more varied meso-pelagic diving profile. The ecological significance and implications of individual foraging specialisation in otariids have had limited attention in the past. Here, we compared the foraging behaviour of female NZ sea lions that use these 2 distinct dive profiles and discuss how the 2 foraging patterns may indicate differing prey choice, as well as their possible implications for individual reproductive ability and interactions with fisheries and, therefore, species demographics. Our ultimate goal is to understand the causes of this individual foraging specialisation and to incorporate such variation when determining management options for this threatened, declining species.
\end{abstract}

KEY WORDS: New Zealand sea lions - Phocarctos hookeri - Individual foraging strategies · Population dynamics · Management

\section{INTRODUCTION}

When describing the foraging ecology of a species, conspecific individuals are often treated as ecological equivalents. However, individual specialisation has potentially important ecological, evolutionary, and conservation implications. Recent research into the diving behaviour of air-breathing vertebrates has found that variation among individuals is no longer considered immaterial noise in foraging behaviour theory, but has become an important determinant of population parameters (e.g. reproductive success and survival) and population viability in its own right (Tremblay \& Cherel 2000, Bradshaw et al. 2004, Costa et al. 2006, Tinker et al. 2008, Villegas-Amtmann et al. 2008).

Individual foraging behaviour results from an interaction between the abundance and distribution of the prey, and the geographic and physiological limits of the predator (Costa 1991a,b, 1993). This interaction has a greater impact on prey choice for diving marine predators than for terrestrial predators: the overlap in prey habitat (particularly depth and heterogeneity of prey distribution), foraging behavior, and physiological limits are more critical in the 3-dimensional aquatic environment, where predators need to hold their breath and thus are constrained by aerobic metabolism when pursuing prey. If marine predators consistently dive for longer than their aerobic capacity, overall diving efficiency is considered to be lowered, impacting survival, reproductive rate, and offspring survival (McCafferty et al. 1998, Tremblay \& Cherel 2000, Bolnick et al. 2003, Costa et al. 2004).

Interspecific variation in vertebrate diving behaviour has been shown to be coupled with species demographics for benthic foraging species (those that dive 
consecutive flat-bottomed dives to the same depth and spend a large proportion of each dive at the benthos), which usually have small population sizes and lower growth rates compared to mesopelagic foraging species (those that forage within the water column) (Tremblay \& Cherel 2000, Costa et al. 2004). This was thought to be the case for New Zealand (NZ) sea lions Phocarctos hookeri, previously identified as benthic foragers with a small, declining population (Gales \& Mattlin 1998, Campbell et al. 2006, Chilvers et al. 2007a). Female NZ sea lions have been reported to be the deepest and longest benthic diving otariid (Gales \& Mattlin 1997, Costa \& Gales 2000, Chilvers et al. 2006). It has been reported that an unusually large proportion of dives (on average $68 \%$ ) exceed their calculated aerobic dive limits (CADL) (Costa \& Gales 2000, Chilvers et al. 2006). However, Chilvers et al. (2006) found that not all female NZ sea lions were benthic divers, instead identifying 2 distinct dive profile types: a benthic diving profile and a more varied mesopelagic diving profile.

There are few other examples of otariid populations with 2 or more distinct foraging behaviours (Northern fur seals Callorhinus ursinus, Goebel et al. 1991, Goebel 1998; Galapagos sea lions Zalophus wollebaeki, Villegas-Amtmann et al. 2008). Individual foraging specialisation in marine predators is often linked to limited or decreasing prey resources (Villegas-Amtmann et al. 2008, Tinker et al. 2008). In the present study, we investigated the diving behaviour and foraging locations of female NZ sea lions that utilise these 2 distinct dive types around the Auckland Islands. We investigated how the specialisation of individuals may affect prey choice, reproductive ability and survival, as well as interactions with the local fishery and possible impacts on overall population viability, species dynamics, and, therefore, management and conservation.

\section{MATERIALS AND METHODS}

Capture and deployment. NZ sea lions are an endemic, threatened, declining species, which have restricted breeding site locations in New Zealand's subantarctic with $83 \%$ of all breeding occurring in the northern Auckland Islands (Hitchmough et al. 2007, Chilvers et al. 2007a). Before commercial sealing, NZ sea lions were distributed along the entire coast of the New Zealand mainland (Childerhouse \& Gales 1998). The present study was conducted at Sandy Bay, Enderby Island, Auckland Islands $\left(50^{\circ} 30^{\prime} \mathrm{S}, 166^{\circ} 17^{\prime} \mathrm{E}\right.$; Fig. 1) during the 2003 and 2004 breeding seasons (January to February). The Sandy Bay colony is the second largest breeding colony of NZ sea lions, with approximately 400 (or $19 \%$ of all) pups born per year
(Chilvers et al. 2007a). Female NZ sea lions come ashore from early December to early January, 1 to $3 \mathrm{~d}$ before giving birth. Mothers give birth to a single pup and remain with it for 5 to $10 \mathrm{~d}$ before returning to sea to forage (Chilvers et al. 2007b). They then alternate between feeding at sea ( 1 to $5 \mathrm{~d}$ ) and nursing the pup ashore ( 1 to 3 d) until pups are weaned at approximately 9 mo of age (Cawthorn et al. 1985, Chilvers et al. 2007b).

VHF transmitters (Sirtrack), satellite-linked platform transmitting terminals (PTTs) (Telonics $300 \mathrm{~mW}$ ST6, potted in epoxy, $130 \times 35 \times 15 \mathrm{~mm}, 175 \mathrm{~g}$; Telonics), and time-depth recorders (TDRs) (Mk9, $40 \times 30 \times$ $22 \mathrm{~mm}$ and $65 \times 18 \times 18 \mathrm{~mm}$; Wildlife Computers) were attached to 18 healthy, branded, female NZ sea lions observed to be suckling a pup. Females were approached while asleep and restrained by placing a net over the head; as the animals moved away and into the net their movements became restricted by its tapering shape. At the end of the net a small reinforced opening held the animal's muzzle, closing the mouth but leaving the nostrils clear (Gales \& Mattlin 1997, Costa \&

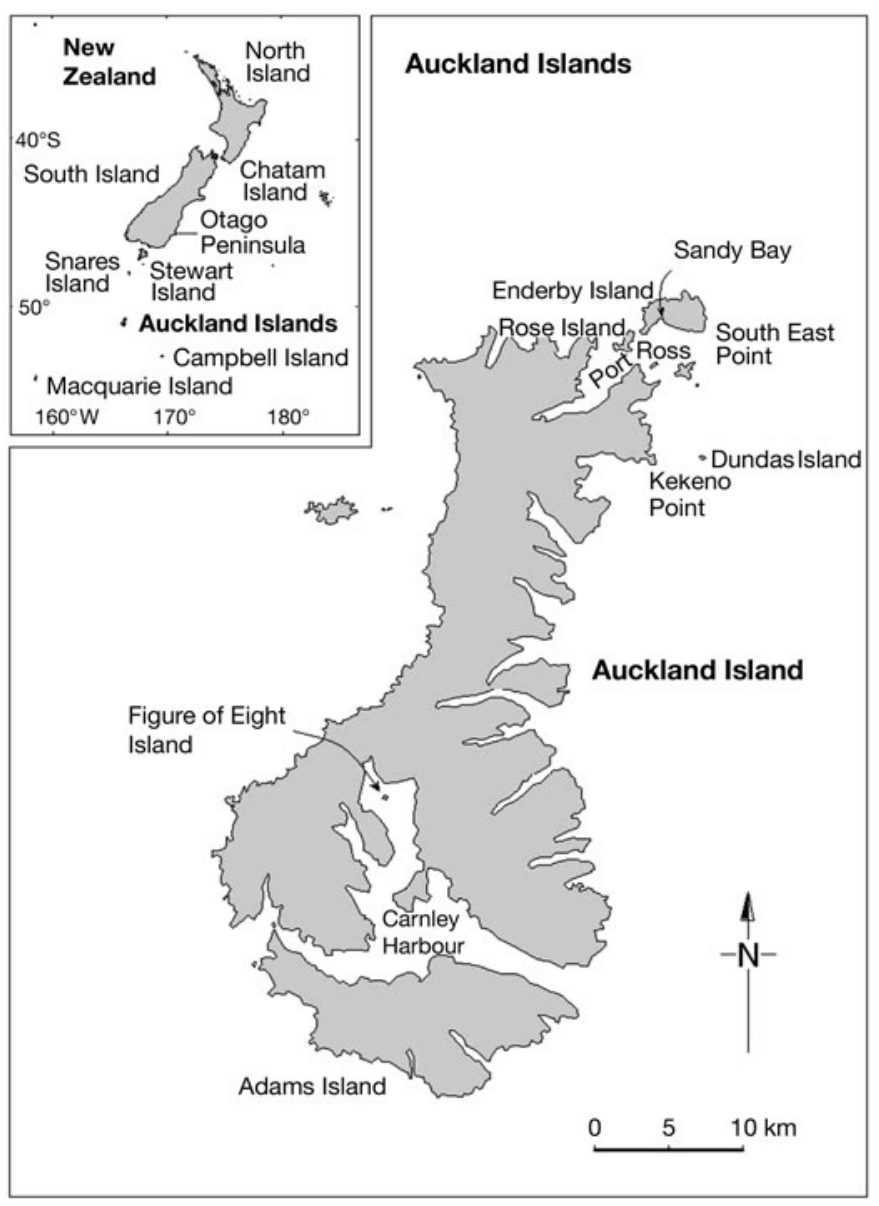

Fig. 1. Phocarctos hookeri. Sandy Bay breeding colony, Enderby Island, Auckland Islands $\left(50^{\circ} 30^{\prime} \mathrm{S}, 166^{\circ} 17^{\prime} \mathrm{E}\right)$ 
Gales 2000). Netted animals were physically restrained by 2 people and anaesthetized using an isoflourane ( 2 to $5 \%$ ) oxygen mix delivered by a mask from a portable vaporizing system (Gales \& Mattlin 1997). From initial netting until the mask was in position took approximately 3 to $5 \mathrm{~min}$, and animals were anaesthetized for less than $30 \mathrm{~min}$. Once stable, the sea lions were weighed (200 kg capacity spring scale $\pm 0.5 \mathrm{~kg}$, Salter Housewares) and measured before instruments were attached. Prior to deployment, each instrument was glued to a piece of neoprene material cut to the same size as the unit's base. This neoprene base was then glued to the dorsal pelage just below the shoulder blades of the sea lion using 2-part epoxy glue. Once the PTT units were adequately attached to the sea lion (8 to 10 min after glue application) the flow of anaesthetic was stopped and the animal was allowed to recover and return to its pup. Each animal was observed after restraint until they were fully conscious and had returned to the group or location where captured. TDRs were programmed to record depth every $5 \mathrm{~s}$ when wet and turn off to save power when dry, thus recording the number and length of dry periods when females were on land. All females with transmitting tags were recaptured in the same manner before the end of the field season (18 February) to retrieve tags. During the recovery process animals were anaesthetized for much shorter periods ( $<15 \mathrm{~min}$ ) because there was no time delay to wait for the glue to set. Tags were removed by horizontally cutting through the neoprene leaving neoprene on the tag and on the animal. This neoprene would be moulted off within a month during the animals' natural moult. All animals were positively identified in the following season and showed no marks or damage in the area where tags were deployed.

Pups from satellite-tagged females were concurrently studied for their growth and mortality rate during the first 2 mo of life (Chilvers et al. 2007b, authors' unpubl. data). Pups were identified and marked between 24 and $36 \mathrm{~h}$ after birth by gluing individually identifiable marker caps to their heads and backs. At this time they were also sexed, weighed, and length and girth measured $( \pm 0.5 \mathrm{~cm})$. After the initial weighing, the pup was not measured or weighed again until the first foraging trip of their mother. Pups were then weighed at varying intervals between $2 \mathrm{~d}$ and 1 wk depending on the mother's attendance pattern (Chilvers et al. 2007b). Pup birth weights, early mortality, and growth rates $\left(\mathrm{g} \mathrm{d}^{-1}\right)$ were compared between the 2 female dive types.

Dive analysis. Diving data were analysed using Multitrace (Jensen Software Systems) to produce summary statistics for each dive. Zero offset drift in the depth values for each tag was corrected manually within Multitrace. Dives $<6 \mathrm{~m}$ in depth were considered to be non-foraging dives primarily associated with travel and were not analysed (Gales \& Mattlin 1997, Chilvers et al. 2006). Bottom time was defined as the time the sea lion spent at depths $>85 \%$ of the maximum depth for that dive (Gales \& Mattlin 1997). Data were analysed for each animal. Dive profiles were classified as benthic and mesopelagic using a similar concept to Tremblay \& Cherel's (2000) intra-depth zone (IDZ). IDZ provides an index of the percentage of dives within a dive bout that are within a given (userdefined) depth range. Tremblay \& Cherel (2000) used an IDZ of $\pm 10 \%$ of previous dives on southern rockhopper penguins Eudyptes chrysocome filholi, which have an average dive depth of $36 \mathrm{~m}$ and maximum dive depth of $70 \mathrm{~m}$. Villegas-Amtmann et al. (2008) used an IDZ of $\pm 10 \mathrm{~m}$ of previous dives rather than a percentage difference on Galapagos sea lion Zalophus wollebaeki, which have an average dive depth of $92 \mathrm{~m}$ and maximum dive depth of $371 \mathrm{~m}$. In the present study, considering NZ sea lions have an average dive depth of $129 \mathrm{~m}$ and maximum dives up to $600 \mathrm{~m}$, we investigated the percentage of dives within a bout which were $\pm 50 \mathrm{~m}$ of the mean depth of the dive bout. This difference in definition was set because of the much greater variability in dive parameters seen for NZ sea lions relative to the other 2 species. For this research, a dive bout was defined as a group of dives separated by short surface intervals (<10 min), ending when a prolonged surface interval or period ashore occurred (surface interval $>10 \mathrm{~min}$ ). This definition is based on NZ sea lion surface interval data showing that $90 \%$ of all surface intervals between dives are $<4 \mathrm{~min}$, and $97 \%$ are $<10 \mathrm{~min}$. A surface interval up to $10 \mathrm{~min}$ in duration is common after long, deep dives (>300 m; B. L. Chilvers unpubl. data); however, surface intervals $>10 \mathrm{~min}$ are uncommon $(3 \%)$, and usually follow a series of shallow dives, indicating a separation of dives into dive bouts rather than animals resting between deep dives.

Benthic dives in pinnipeds are characterised by several criteria, including square dive shape (a steady decent followed by extended time spent at a relatively constant depth followed by a steady ascent), the uniform maximum depth of a series of dives, and the lack of deeper dives within the series, suggesting that the sea floor limits the depth to which animals dive (Hindell et al. 1991, Werner \& Campagna 1995, Gales \& Mattlin 1997). The cADL for each female within the present study was estimated based on a usable oxygen store of $47.4 \mathrm{ml} \mathrm{O}_{2} \mathrm{~kg}^{-1}$ (Costa et al. 1998) and assuming a diving metabolic rate of $58.7 \mathrm{ml} \mathrm{O} \mathrm{kg}^{-0.75} \mathrm{~min}^{-1}$ (Costa \& Gales 2000). All results are presented as mean \pm 1 SE. Pearson's correlation analysis and 1-way ANOVAs were conducted using SPSS. 
Satellite locations. At-sea locations were calculated for each sea lion by reference to 3 satellites and were assigned to 6 classes by Argos on the basis of their accuracy. Since NZ sea lions dive almost continuously while at sea (Gales \& Mattlin 1997, Chilvers et al. 2006), all trips and satellite locations were assumed to be part of a foraging trip and to represent foraging locations. Locations were filtered by an algorithm described by McConnell et al. (1992). This iterative forward/backward averaging filter identifies fixes that would require an unrealistic rate of travel. We used a maximum swimming speed parameter of $2 \mathrm{~m} \mathrm{~s}^{-1}$ (Crocker et al. 2001, Chilvers et al. 2005). Locations with a running mean speed greater than this value were excluded as outliers.

Filtered locations were used to estimate distance from Enderby Island and total distance travelled. Calculations of mean distance travelled per trip, maximum distance from the breeding colony, and kernel ranges (KRs) (Worton 1989) were restricted to complete trips (defined as animals' locations that were at the colony or within $10 \mathrm{~km}$ from the colony while the animals were travelling towards it). Locations from incomplete trips are represented in figures and tables but were not used in trip statistics, as they did not rep- resent full return trips. KRs for 50 and $65 \%$ of all locations per animal were created using the Animal Movement Extension of ARCVIEW (Hooge et al. 2000). These ranges were thought to show representative foraging locations (Chilvers et al. 2005) and were calculated using smoothing factors calculated via leastsquare cross-validation (Seaman \& Powell 1996). These 2 KRs were then averaged and used to compare representative foraging area size between individuals. No differences were found between weighted (by number of sightings) and unweighted averages, indicating that the number of sightings for each individual did not influence kernel range size estimates (Chilvers et al. 2005).

\section{RESULTS \\ Diving}

Satellite and dive instruments were attached to $18 \mathrm{fe}$ male NZ sea lions for between 5 to $34 \mathrm{~d}$. Dive data were collected from the 18 sea lions over 137 foraging trips with 54106 dives logged on these trips. From these 18 females, 2 distinct dive profiles were defined: benthic

Table 1. Phocarctos hookeri. Summary of diving records, foraging cycle, and behaviour of 18 female New Zealand sea lions. Dives are defined as submersions $>6 \mathrm{~m}$. Aerobic dive limits (ADLs) were estimated based on a useable oxygen store of $47.4 \mathrm{ml}$ $\mathrm{O}_{2} \mathrm{~kg}^{-1}$ (Costa et al. 1998) and assuming a diving metabolic rate of $58.7 \mathrm{ml} \mathrm{O}_{2} \mathrm{~kg}^{-0.75} \mathrm{~min}^{-1}$ (Costa \& Gales 2000). B: Benthic; M: mesopelagic; significance: difference between B and M divers; ns: not significant, $\mathrm{p}>0.05$. Data are mean $\pm \mathrm{SE}$

\begin{tabular}{|c|c|c|c|c|c|c|c|c|c|c|c|c|}
\hline $\begin{array}{l}\text { Female } \\
\text { ID (mass } \\
\text { at deploy- } \\
\text { ment, kg) }\end{array}$ & $\begin{array}{l}\text { Dive } \\
\text { profile } \\
\text { type }\end{array}$ & $\begin{array}{l}\% \text { of } \\
\text { le dives } \\
\pm 25 \mathrm{~m} \text { of } \\
\text { mean dive } \\
\text { bout deptr }\end{array}$ & $\begin{array}{l}\text { Dives } \\
\text { per } \\
\text { foraging } \\
\text { fe cycle } \\
\text { h }\end{array}$ & $\begin{array}{l}\text { Dives } \\
\text { per } \\
\text { hour } \\
\text { at sea }\end{array}$ & $\begin{array}{c}\text { Surface } \\
\text { interval } \\
\text { mean (min) } \\
\text { SE (s) }\end{array}$ & $\begin{array}{l}\text { Dive } \\
\text { depth } \\
\text { (m) }\end{array}$ & $\begin{array}{c}\text { Dive } \\
\text { duration } \\
\text { (mean: min; } \\
\text { SE: s) }\end{array}$ & $\begin{array}{c}\text { Bottom } \\
\text { time } \\
(\%)\end{array}$ & $\begin{array}{l}\text { Time } \\
\text { at sea } \\
(\mathrm{h})\end{array}$ & $\begin{array}{c}\text { Time } \\
\text { submerged } \\
\text { at sea } \\
(\%)\end{array}$ & $\begin{array}{l}\text { ADL } \\
\text { (min) }\end{array}$ & $\begin{array}{c}\text { Dives } \\
\text { that } \\
\text { exceed } \\
\text { ADL } \\
(\%)\end{array}$ \\
\hline 1433 (119.0) & ) $B$ & 84 & 669.8 & 6.3 & $4.9 \pm 18.8$ & $142 \pm 0.84$ & $4.42 \pm 1.2$ & $48 \pm 2$ & 86.6 & 46.3 & 3.46 & 88.4 \\
\hline 1492 (124.5) & ) $B$ & 68 & 363.4 & 6.5 & $4.7 \pm 20.1$ & $179 \pm 1.58$ & $4.97 \pm 1.7$ & $38 \pm 4$ & 52.8 & 53.8 & 3.75 & 80.6 \\
\hline 1397 (123.5) & $\mathrm{B}$ & 84 & 773.8 & 7.8 & $2.7 \pm 7.5$ & $114 \pm 0.53$ & $4.29 \pm 0.9$ & $54 \pm 2$ & 75.7 & 55.1 & 3.69 & 84.4 \\
\hline 1391 (105.0) & $\mathrm{B}$ & 88 & 375.3 & 8.5 & $3.1 \pm 11.4$ & $134 \pm 1.24$ & $4.48 \pm 1.6$ & $49 \pm 3$ & 40.2 & 63.2 & 2.78 & 84.0 \\
\hline $1458(113.0)$ & ) $\mathrm{B}$ & 81 & 759.0 & 7.9 & $3.7 \pm 11.1$ & $119 \pm 0.82$ & $4.01 \pm 1.2$ & $51 \pm 2$ & 80.7 & 53.2 & 3.16 & 81.2 \\
\hline 1484 (91.5) & $\mathrm{B}$ & 83 & 515.6 & 9.3 & $2.5 \pm 7.2$ & $110 \pm 0.45$ & $4.39 \pm 0.8$ & $55 \pm 2$ & 53.3 & 70.3 & 2.19 & 90.6 \\
\hline $1462(114.5)$ & ) $B$ & 84 & 503.7 & 8.3 & $5.8 \pm 26.3$ & $119 \pm 1.08$ & $4.18 \pm 1.7$ & $45 \pm 3$ & 71.3 & 51.2 & 3.24 & 77.5 \\
\hline $1400(99.0)$ & B & 78 & 923.0 & 9.9 & $1.5 \pm 5.1$ & $95 \pm 1.09$ & $3.92 \pm 1.7$ & $59 \pm 3$ & 66.4 & 73.5 & 2.51 & 85.1 \\
\hline 1385 (116.0) & ) $\mathrm{B}$ & 76 & 475.5 & 7.8 & $4.8 \pm 20.4$ & $98 \pm 0.85$ & $3.37 \pm 1.2$ & $42 \pm 3$ & 57.1 & 44.1 & 3.31 & 62.5 \\
\hline 1443 (103.0) & $\mathrm{B}$ & 83 & 457.4 & 9.8 & $2.3 \pm 7.2$ & $101 \pm 0.70$ & $3.96 \pm 1.1$ & $57 \pm 2$ & 42.5 & 64.7 & 2.69 & 86.3 \\
\hline 1399 (109.5) & $\mathrm{M}$ & 31 & 266.9 & 7.2 & $4.6 \pm 21.4$ & $147 \pm 1.88$ & $3.64 \pm 1.9$ & $30 \pm 5$ & 33.7 & 43.5 & 2.99 & 57.3 \\
\hline 1409 (119.0) & $\mathrm{M}$ & 36 & 360.7 & 7.3 & $5.4 \pm 29.5$ & $170 \pm 2.05$ & $3.89 \pm 1.9$ & $25 \pm 5$ & 55.7 & 47.5 & 3.46 & 60.2 \\
\hline 1470 (120.5) & $\mathrm{M}$ & 27 & 381.3 & 6.5 & $5.8 \pm 30.6$ & $128 \pm 3.74$ & $3.56 \pm 4.0$ & $22 \pm 8$ & 59.9 & 39.5 & 3.54 & 39.4 \\
\hline 1456 (103.0) & $\mathrm{M}$ & 23 & 296.2 & 7.4 & $4.0 \pm 12.4$ & $135 \pm 2.28$ & $3.51 \pm 2.1$ & $27 \pm 5$ & 34.3 & 48.6 & 2.69 & 52.6 \\
\hline 1371 (141.5) & $\mathrm{M}$ & 28 & 496.0 & 8.2 & $3.5 \pm 27.1$ & $134 \pm 5.36$ & $4.11 \pm 5.0$ & $27 \pm 13$ & 31.8 & 57.0 & 4.69 & 33.9 \\
\hline 1439 (104.5) & $\mathrm{M}$ & 38 & 361.0 & 6.6 & $6.5 \pm 24.1$ & $131 \pm 1.99$ & $3.59 \pm 2.2$ & $32 \pm 5$ & 54.8 & 39.4 & 2.76 & 62.9 \\
\hline 1438 (109.0) & $\mathrm{M}$ & 35 & 291.4 & 8.4 & $3.2 \pm 11.8$ & $130 \pm 2.69$ & $3.45 \pm 2.6$ & $32 \pm 7$ & 29.8 & 52.1 & 2.97 & 56.8 \\
\hline $1406(133.0)$ & $\mathrm{M}$ & 38 & 682.3 & 6.5 & $5.7 \pm 18.7$ & $143 \pm 2.09$ & $4.14 \pm 2.7$ & $29 \pm 5$ & 64.2 & 45.2 & 4.21 & 46.2 \\
\hline \multicolumn{2}{|c|}{ Benthic mean } & $81 \pm 1.8$ & $582 \pm 59.6$ & $8.2 \pm 0.39$ & $3.6 \pm 4.6$ & $121 \pm 8.0$ & $4.2 \pm 0.13$ & $50 \pm 2.1$ & $62.6 \pm 5.0$ & $57.5 \pm 3.1$ & 3.1 & $82.1 \pm 2.5$ \\
\hline \multicolumn{2}{|c|}{$\begin{array}{l}\text { Mesopelagic } \\
\text { mean }\end{array}$} & $32 \pm 1.9$ & $392 \pm 48.6$ & $7.3 \pm 0.25$ & $5.0 \pm 8.3$ & $140 \pm 4.8$ & $3.7 \pm 0.09$ & $28 \pm 0.35$ & $45.5 \pm 5.1$ & $46.6 \pm 2.1$ & 3.4 & $51.2 \pm 2.5$ \\
\hline \multicolumn{3}{|l|}{ Significance } & $\begin{array}{l}F=5.7 \\
\mathrm{p}=0.03\end{array}$ & $\begin{array}{l}F=3.6 \\
\mathrm{p}=0.07\end{array}$ & $\begin{array}{c}F=87.9 \\
p<0.0001\end{array}$ & ns & $\begin{array}{c}F=7.1 \\
\mathrm{p}=0.017\end{array}$ & $\begin{array}{c}F=68.5 \\
p<0.0001\end{array}$ & $\begin{array}{l}F=5.5 \\
\mathrm{p}=0.03\end{array}$ & $\begin{array}{l}F=7.4 \\
\mathrm{p}=0.01\end{array}$ & ns & $\begin{array}{r}F=51.9 \\
\mathrm{p}<0.0001\end{array}$ \\
\hline \multicolumn{3}{|l|}{ Overall mean } & $498 \pm 44.7$ & $7.8 \pm 0.27$ & $4.2 \pm 4.2$ & $129 \pm 5.3$ & $3.9 \pm 1.9$ & $40 \pm 2.9$ & $54.1 \pm 1.66$ & $52.7 \pm 2.343$ & $2 \pm 0$ & $68.7 \pm 4.37$ \\
\hline
\end{tabular}




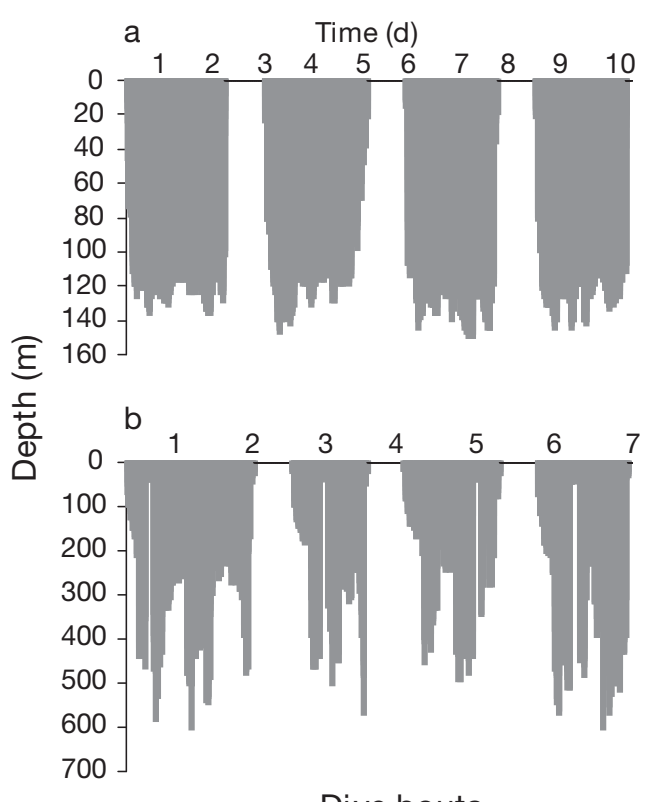

Dive bouts

Fig. 2. Phocarctos hookeri. Examples of the 2 distinct dive profiles for the foraging cycles of female New Zealand sea lions: (a) benthic and (b) mesopelagic. Note the difference in depth scale on each graph

$(\mathrm{n}=10)$ and mesopelagic $(\mathrm{n}=8)$ (Chilvers et al. 2006) (Table 1, Figs. 2a,b). All females fell clearly into one of the 2 dive profile types, and, from concurrent research, these dive types and foraging locations were shown to be consistent across years despite probable changes in environment and prey availability (Chilvers 2008b). Both dive patterns and profiles have previously been found for other otariids, however, entire species are usually defined as undertaking one profile type or the other with few exceptions (Goebel et al. 1991, Goebel 1998, Arnould \& Costa 2006, Costa et al. 2006, VillegasAmtmann et al. 2008). On average, benthic divers averaged $81 \%$ of all dives within $50 \mathrm{~m}$ of the mean dive bout depth (range $=68$ to $88 \%$ ), while mesopelagic divers averaged $32 \%$ of all dives within $50 \mathrm{~m}$ of the mean dive bout depth (range $=23$ to $38 \%$ ) (Table 1). Frequency of dive depths varied significantly between the 2 dive profiles (Fig. 3). Over $55 \%$ of dives performed by benthic divers were between 100 and $200 \mathrm{~m}$, and $<5 \%$ were less than $50 \mathrm{~m}$ (Fig. 3a). In contrast, mesopelagic divers performed $\sim 50 \%$ of dives at $>150 \mathrm{~m}$ in addition to many shallower dives, with $33 \%$ of dives at $<50 \mathrm{~m}$ (Fig. 3b). For mesopelagic divers, we found that of those dives that followed deep ( $>200 \mathrm{~m}$ ) dives, $20 \%$ ( $\mathrm{n}=1163$ out of 5884 dives) were shallow $(<50 \mathrm{~m})$, while for benthic divers only $6 \%$ ( $n=136$ out of 2196 dives) of deep dives were followed by shallow dives.

Table 1 presents dive statistics for the 18 female sea lions. The mean number of dives per foraging cycle (foraging cycle $=$ mean time ashore + mean time at sea) differed significantly between the dive profile types, with benthic divers having more dives per cycle than mesopelagic divers (582 and 392, respectively, $F=5.7$, $\mathrm{df}=17, \mathrm{p}=0.03$ ) (Table 1). There was a trend for benthic divers to also have a higher number of dives per hour at sea (Table 1). Mesopelagic divers had a significantly higher surface interval between dives than benthic divers ( 5 and $3.6 \mathrm{~min}$, respectively, $F=87.9$, $\mathrm{df}=17, \mathrm{p}<0.0001)($ Table 1). There was no significant difference between mean dive depths for the 2 dive profiles. However, benthic divers had a significantly longer average dive duration than mesopelagic divers (4.2 and $3.7 \mathrm{~min}$, respectively, $F=7.1, \mathrm{df}=17, \mathrm{p}=$ 0.017 ) and spent longer in the bottom $85 \%$ of dive depth (50 and $28 \%$ of time, respectively, $F=68.5, \mathrm{df}=$ $17, \mathrm{p}<0.0001$ ) (Table 1).

For both dive profiles, dive depth and dive duration were positively correlated, with deeper dives being of longer duration (overall $r=0.796, p<0.001$ ). Similarly, dive depth was negatively correlated with the proportion of time spent at $>85 \%$ of dive depth, with deeper dives having significantly shorter bottom time (overall $r=-0.370, p<0.001)$. There was also a positive correlation between the percentage of time females spent submerged $(>6 \mathrm{~m}$ ) each foraging cycle and the number

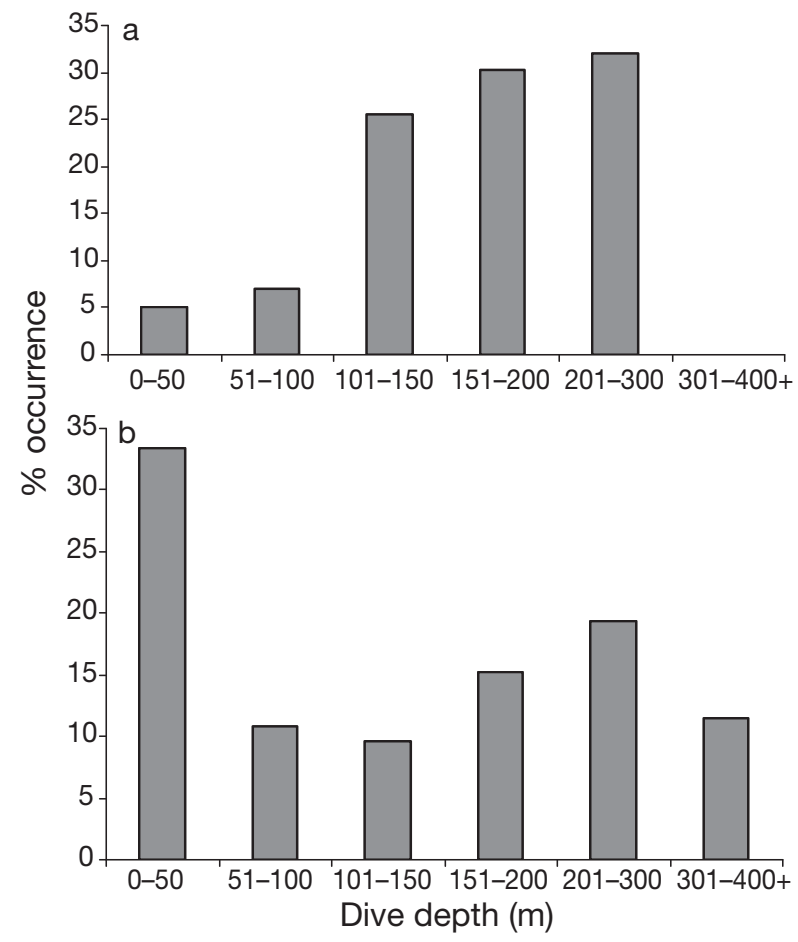

Fig. 3. Phocarctos hookeri. Frequency distribution of dives at various dive depths from (a) benthic and (b) mesopelagic diving female New Zealand sea lions 


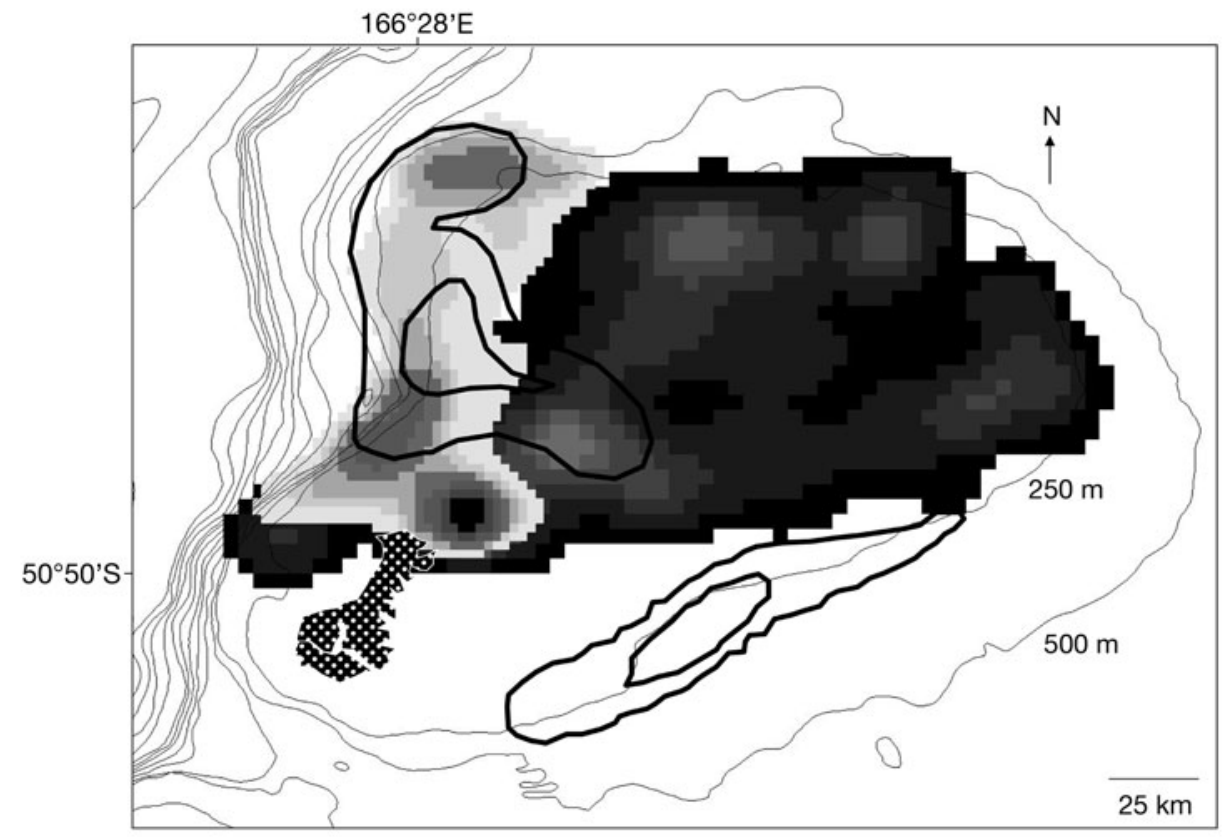

Fig. 4. Phocarctos hookeri. Kernel home ranges (KHR) of all filtered satellite locations from 14 female New Zealand sea lions during January and February for the austral summers 2003 to 2004. The 9 benthic divers are represented by dark coloured KHR with intensity of colour representing percentage of time spent in the area; colour scales range from black (95\% of all satellite locations) to white ( $5 \%$ of all satellite locations). The 5 mesopelagic divers are represented by the light coloured KHR with colour intensity ranging from light grey (95\% of all locations) to black (5\% of all locations). Thick black lines: squid trawl fishery effort (50 and $95 \%$ kernel ranges 2001-2004); thin black lines: bathymetric contours; dotted: Auckland Island. Scale bar $=25 \mathrm{~km}$

of dives per hour for both dive profiles (overall $\mathrm{r}=$ $-0.795, \mathrm{p}<0.001)$.

For benthic divers, the mean number of dives per hour was positively correlated with the percentage of bottom time and negatively correlated with dive depth $(r=0.207$ and -0.283 , respectively, $p<0.0001)$. Therefore, the greater the rate of diving (dives per hour), the lower the mean dive depth and the longer the percentage of time spent at the bottom of the dive. This relationship was not seen in mesopelagic divers. There was a negative correlation between the percentage of time females spent submerged each foraging cycle and their dive depth, with females who performed deeper dives having shorter submerged times $(\mathrm{r}=-0.102, \mathrm{p}<$ 0.001). Correspondingly, for benthic divers there were weak positive correlations between: (1) total submerged time for a foraging trip with dive duration; (2) percentage of bottom time with longer dives; and (3) bottom time with overall time submerged per foraging trip $(\mathrm{r}=0.099,0.097$ and 0.204 , respectively, $\mathrm{p}<$ 0.001). In contrast, mesopelagic divers showed none of these correlations. These results parallel our findings that rate of diving, depth of dives, and percentage bottom time were correlated, and illustrate further differences between the 2 dive profiles for female NZ sea lions (Table 1).

Table 1 also summarises the foraging cycle lengths and estimates of CADL for each NZ sea lion female and the percentage of dives that exceed their cADLs. There was no difference in female age or body mass between individuals performing the 2 dive profiles. Benthic divers spent a significantly longer period at sea than mesopelagic divers (62.6 and $45.5 \mathrm{~h}$, respectively, $F=$ $5.5, \mathrm{df}=17, \mathrm{p}=0.03)$; however, there was no difference in the percentage of time they spent at sea within a particular foraging cycle, as they spent slightly longer times ashore than mesopelagic divers. Benthic divers spent a significantly higher proportion of time submerged while at sea $(57.5$ and $46.6 \%$, respectively, $F=$ $7.4, \mathrm{df}=17, \mathrm{p}=0.01$ ) and exceeded their cADLs significantly more than mesopelagic divers (82 and $51 \%$, respectively, $F=51.9, \mathrm{df}=17, \mathrm{p}<0.0001)($ Table 1$)$.

\section{Satellite locations}

The KRs of the satellite foraging locations of 14 of the 18 females divided by dive type are shown in Fig. 4. There was a considerable difference in foraging location between the 2 dive profile types, with all benthic divers foraging north and northeast of Enderby Island, over the Auckland Island shelf (Fig. 4), whereas all mesopelagic divers foraged north and northwest along the edge of the shelf where it drops steeply to $3000 \mathrm{~m}$ (Fig. 4). There were no significant differences between benthic and mesopelagic divers for maximum distance 
travelled from the colony, kernel range sizes, or the mean straight line distances from the colony to the centre of the kernel range, although benthic divers showed greater distances in all categories. The distance travelled from the colony for benthic divers was $122 \pm 11.6 \mathrm{~km}$ (range $=58$ to $162 \mathrm{~km}$ ) and for mesopelagic divers it was $98 \pm 13.8 \mathrm{~km}$ (range $=70$ to $145 \mathrm{~km})$. Kernel range of foraging areas was higher in benthic divers $\left(50 \% \mathrm{KR}, 181 \pm 43.8 \mathrm{~km}^{2} ; 65 \% \mathrm{KR}, 352 \pm\right.$ $\left.89.1 \mathrm{~km}^{2}\right)$ than in mesopelagic divers $(50 \% \mathrm{KR}, 130 \pm$ $24.5 \mathrm{~km}^{2}$; $65 \% \mathrm{KR}, 234 \pm 45.2 \mathrm{~km}^{2}$ ). Distances between the central kernel range and the colony were also higher in benthic divers $(73 \pm 11.4 \mathrm{~km})$ than in meospelagic divers $(57 \pm 16.3 \mathrm{~km})$. A comparison of the foraging locations of these 2 dive profiles with the arrow squid trawl fishery activity on the Auckland Island shelf indicates that the mesopelagic divers have a much greater overlap with the fishery than the benthic divers, both in terms of location and depth of fisheries operations (Fig. 4). This overlap would lead to a higher risk of interaction and death for mesopelagic divers.

\section{Pup growth and survival}

There were no significant differences in pup birth weights, growth, or mortality rates (within the first 2 mo of their lives) for the pups from benthic or mesopelagic divers. Mean pup birth weights for benthic $(10 \pm 0.33 \mathrm{~kg})$ and mesopelagic divers (10.1 \pm $0.36 \mathrm{~kg}$ ) were similar, as were growth rates (benthic $=$ $156 \pm 14.8 \mathrm{~g} \mathrm{~d}^{-1}$, mesopelagic $\left.=148 \pm 34.6 \mathrm{~g} \mathrm{~d}^{-1}\right)$. Pup mortality was higher in benthic divers $(41 \%, 5$ pups out of 12$)$ than in mesopelagic divers $(25 \%, 2$ out of 8$)$, but this was not significant. Sample sizes and length of study for these comparisons were small, so results should be interpreted with caution.

\section{DISCUSSION}

Lactating female NZ sea lions are known to be the deepest, longest diving otariids, diving almost continuously while at sea with many dives exceeding their cADL (Gales \& Mattlin 1997, Costa et al. 1998, 2001, Costa \& Gales 2000, Crocker et al. 2001, Chilvers et al. 2006, present study). They show high levels of individual variation in foraging behaviour and location, however, individuals repeatedly return to specific foraging areas within and between breeding seasons despite environmental variability (Chilvers et al. 2005, Chilvers 2008b). Until recently, NZ sea lions were thought to have benthic diving behaviours only, a diving behaviour which theoretically matches their small popu- lation numbers which are in slow decline (Campbell et al. 2006, Chilvers et al. 2007a). However, the present study has shown that there are 2 distinct dive type foraging behaviours, with individuals having differing foraging locations, resulting in varying degrees of overlap with fishery activity and, therefore, differences in bycatch mortality. All females in this research fell clearly into one or the other dive profile type and, from concurrent research, these dive types and foraging locations were shown to be consistent across years (Chilvers 2008b).

The benthic diving profile appears to be a more energetically expensive foraging behaviour than alternative foraging strategies (Costa et al. 2006, present study). In comparison with mesopelagic divers, benthic divers spend more time at sea per foraging cycle, spend a higher percentage of overall time submerged, undertake a greater number of dives per hour and per foraging trip, have greater dive durations, spend more time in the bottom $85 \%$ of their dive depths, and their dives exceed their cADLs $30 \%$ more than mesopelagic divers (Table 1). Similar results are also seen for other otariids including Australian sea lions Neophoca cinerea, Southern sea lions Otaria flavescens, and Australian fur seals Arctocephalus pusillus doriferus (Costa et al. 2001, 2004). Examination of the satellite locations of these individuals also show that benthic divers tend to forage greater distances from the breeding area and their foraging is spread over a wider area, which increases the energy and time required for foraging (Table 1, Fig. 4). A comparison of the foraging locations of individuals with these 2 dive profiles with subantarctic squid trawl fishery activity indicate that mesopelagic divers have a much greater overlap with the fishery than benthic divers, both in terms of location and depth of fisheries activities (Chilvers et al. 2005, 2006, Chilvers 2008b) (Fig. 4). This may prove to be a significant selection force against mesopelagic foragers, with implications for loss of genetic diversity for this species. It may skew the proportion of female NZ sea lions in each foraging strategy to benthic foraging, as benthic divers are less likely to get caught and killed as bycatch and have less potential resource competition, even though this may be energetically a less viable foraging strategy.

Why females choose to forage using one dive type or the other is unclear. However, physiological capacity is an important determinant of behaviour and plays an important role in determining foraging strategy (Costa et al. 2001, Arnould \& Costa 2006, Costa et al. 2006). We found no significant differences in body mass or age of females between the 2 dive profiles, thus indicating that individual foraging strategy may be determined by behaviour rather than age or mass characteristics. This, coupled with the individual consistency in 
foraging areas and dive profiles between and within years for NZ sea lions, indicates that foraging behaviour is a long-term learnt behaviour (Chilvers et al. 2005, Chilvers 2008b). This consistency in foraging strategy regardless of age or mass (which relates to factors such as total body oxygen stores and, therefore, impacts cADL calculations) has not been demonstrated in any other otariid, including those that have shown distinct individual foraging strategies such as the Galapagos sea lion (Villegas-Amtmann et al. 2008).

The 2 dive profiles observed for lactating NZ sea lions are likely correlated with differing prey availability and, therefore, diet. NZ sea lions are thought to be opportunistic feeders, however, this assumption was made based on scat samples from unknown individuals (Childerhouse et al. 2001). Diet analysis shows that the predominant prey types taken, both in number and mass, around the Auckland Islands are octopus Octopus spp., arrow squid Nototodarus sloanii, rattail Coelorhynchus spp., juvenile red cod Pseudophycis bachus, and opalfish Hemerocoetes spp. (Childerhouse et al. 2001, L. Meynier unpubl. data). Individual foraging behaviour and differing diets have been observed in other marine mammals, such as bottlenose dolphins Tursiops aduncas and T. truncatus in Australia (Smolker et al. 1997, Chilvers \& Corkeron 2001, Sargeant et al. 2005) and orcas Orcinus orca in Canada (Ford et al. 1998, Baird 2000). The relationship between these 2 dive profiles and diet is currently being investigated using fatty acid analysis (L. Meynier unpubl. data). However, given our knowledge of prey distribution, it can be hypothesised that the diet of benthic divers would be comprised of benthic-living prey, including octopus and opalfish, whereas the diet of mesopelagic divers is more likely to include rattail and squid, the greatest concentrations of which are midwater in >200 $\mathrm{m}$ deep water in the Auckland Island shelf area (Mattlin et al. 1985).

For NZ sea lions, it is unlikely that the more energetically expensive benthic foraging behaviour is compensated for by a high energy diet. The energy values of benthic species such as octopus and opalfish are no greater than those for squid or rattail, all $<4 \mathrm{~kJ} \mathrm{~g}^{-1}$ (Braster 1991, Goodman-Lowe et al. 1999, Rosen \& Trites 2000). However, one benefit of benthic prey species is that they tend to be a predictable, evenly distributed prey source, albeit occurring at low densities within a habitat. In contrast, mesopelagic prey tend to occur in unpredictable, high density patches, providing a rich food source once located. Benthic prey are also less influenced by oceanographic perturbations such as El Niño than mesopelagic prey (Miller \& Sydeman 2004). The more energetically expensive benthic foraging behaviour may be expected to result in lower reproductive success for females, as benthic divers spend significantly longer times at sea foraging than mesopelagic divers (Miller \& Sydeman 2004). However, from our limited dataset, there was no apparent effect of foraging strategy on pup birth weights, growth rates, or pup mortality.

Multiple distinct foraging strategies have been observed in other marine predators such as Northern fur seals (Goebel et al. 1991), Galapagos sea lions (Villegas-Amtmann et al. 2008), and California sea otters Enhydra lutris nereis (Tinker et al. 2008). For sea lions and sea otters, foraging specialisation was hypothesised to be linked with low or decreasing prey resources, requiring prey specialisation for species survival. The 2 distinct foraging behaviours seen for female NZ sea lions likely partition the use of resources both in terms of location and concentration. Of the 2 diving types, benthic divers may be more vulnerable to changes in their environment due to their more specialised feeding technique, particularly when considering some fisheries practices such as bottom trawling (Costa 1993). Bottom trawling is used by the squid fleet which operates around the Auckland Islands, and it impacts the benthic environment and, therefore, prey availability and distribution. A further compounding problem for benthic divers is the possibility that juvenile animals may experience lower survival than adults: since adults operate at their physiological limit, juveniles, who have lower physiological capacities than adults due to their smaller body size and inexperience, would have an even harder time foraging benthically. This has been observed for the benthic foraging Australian sea lions (Fowler et al. 2006, 2007). If this is also the case for NZ sea lions, then juvenile survival would be lower for benthic divers than for mesopelagic divers. In contrast, it is the mesopelagic divers that have the greatest overlap with fisheries operations (Fig. 4), increasing their chances of interaction and death from fisheries. Resource partitioning may buffer the effects of an overlap with fisheries or environmental changes that influence the distribution and abundance of prey.

NZ sea lions are a threatened endemic species; they have shown a $30 \%$ decline in pup production in the last 8 yr (1998 to 2006) and were considered to be exclusively benthic foragers operating at their physiological limits in a restricted area that is impacted by commercial fisheries (Costa \& Gales 2000, Chilvers et al. 2005, 2006, Chilvers 2008a). Animals that operate at or near their maximum physiological abilities are less likely to have the capacity to increase their foraging effort in response to reductions in food availability, whether due to environmental changes, fisheries related activities, or both. Other benthic foraging otariids have also been shown to have stable or declining populations that are small relative to mesopelagic for- 
aging otariids (Arnould \& Costa 2006, Costa et al. 2006), indicating that this may be a natural state for NZ sea lions. However, NZ sea lions were previously distributed along the entire coast of the New Zealand mainland (Childerhouse \& Gales 1998), and, as seen in the present study, not all female NZ sea lions are benthic foragers. The use of 2 diving patterns and foraging locations by breeding females, and likely dietary differences, may explain why this species is exhibiting only a slow decline, despite having been under significant fisheries pressure since the 1970s (Chilvers 2008a). Foraging diversity may also buffer the impact of environmental variability, such as El Niño or climate change, within their restricted breeding area. This possible influence needs to be taken into consideration when modelling the population dynamics of this species and for management in relation to fisheries interactions. Impacts such as mortality in fisheries may be having a greater impact on the population than can be immediately detected due to the buffering effect from 2 foraging strategies. However, if the proportion of each foraging strategy in the population alters significantly or one disappears, this may cause a severe change in the species' resilience to either anthropogenic impacts or environmental change and lead to the endangerment of this already threatened species.

Acknowledgements. This work was conducted under permit from the New Zealand Department of Conservation (DOC), and was funded by DOC, R,D\&I Division (investigation no. 1638). DOC Southern Islands are thanked for their logistical assistance. We also thank P. Duignan, J. Amey, A. Castinel, S. Childerhouse, W. Hockley, P. McClelland, F. Riet Sapriza, and $\mathrm{M}$. Wylie for assistance with captures in the field. Approval for work was obtained from DOC Animal Ethics Committee (approval AEC86, 1 July 1999). I. West, A. Todd, and 2 anonymous reviewers provided helpful, critical reviews of the manuscript.

\section{LITERATURE CITED}

Arnould JPY, Costa DP (2006) Sea lions in drag, fur seals incognito: insights from the Otariid deviants. In: Trites AW, DeMaster DP, Fritz LW, Gelatt LD, Rea LD, Wynne KM (eds) Sea lions of the world. Alaska Sea Grant College Program, University of Alaska, Fairbanks, p 111-125

Baird RW (2000) The killer whale: foraging specializations and group hunting. In: Mann J, Connor RC, Tyack PL, Whitehead H (eds) Cetacean societies: field studies of dolphins and whales. The University of Chicago Press, Chicago, IL, p 127-153

Bolnick DI, Svanback R, Fordyce JA, Yang LH, Davis JM, Hulsey CD, Forister ML (2003) The ecology of individuals: incidence and implications of individual specialization. Am Nat 161:1-28

Bradshaw CJA, Hindell MA, Sumner MD, Michael KJ (2004) Loyalty pays: potential life history consequences of fidelity to marine foraging regions by southern elephants seals. Anim Behav 68:1349-1360
Braster J (1991) New Zealand seafood manual. New Zealand Fishing Industry Board, Wellington

Campbell RA, Chilvers BL, Childerhouse S, Gales NJ (2006) Conservation management issues and status of the New Zealand (Phocarctos hookeri) and Australian (Neophoca cinerea) sea lions. In: Trites AW, DeMaster DP, Fritz LW, Gelatt LD, Rea LD, Wynne KM (eds) Sea lions of the world. Alaska Sea Grant College Program, University of Alaska, Fairbanks, p 455-471

Cawthorn MW, Crawley MC, Mattlin RH, Wilson GJ (1985) Research on pinnipeds in New Zealand. Wildlife Research Liaison Group Report no. 7, Wellington

Childerhouse S, Gales N (1998) Historical and modern distribution and abundance of the New Zealand sea lion, Phocarctos hookeri. NZ J Zool 25:1-16

Childerhouse S, Dix B, Gales NJ (2001) Diet of New Zealand sea lions (Phocarctos hookeri) at the Auckland Islands. Wildl Res 28:291-298

Chilvers BL (2008a) New Zealand sea lions, Phocarctos hookeri, and squid trawl fisheries: bycatch problems and management options. Endang Species Res 5:193-204

Chilvers BL (2008b) Foraging site fidelity of lactating New Zealand sea lions, Phocarctos hookeri. J Zool Lond 276: 28-36

Chilvers BL, Corkeron PJ (2001) Trawlers and bottlenose dolphins' social structure. Proc R Soc Lond B 268:1901-1905

Chilvers BL, Wilkinson IS, Duignan PJ, Gemmell NJ (2005) Summer foraging areas for lactating New Zealand sea lions Phocarctos hookeri. Mar Ecol Prog Ser 304:235-247

Chilvers BL, Wilkinson IS, Duignan PJ, Gemmell N (2006) Diving to extremes: Are New Zealand sea lions (Phocarctos hookeri) pushing their limits in a marginal habitat? J Zool Lond 269:233-241

Chilvers BL, Wilkinson IS, Childerhouse S (2007a) New Zealand sea lion, Phocarctos hookeri, pup production: 1995 to 2005. NZ J Mar Freshw Res 41:205-213

Chilvers BL, Robertson BC, Wilkinson IS, Duignan P (2007b) Growth and survival of New Zealand sea lions, Phocarctos hookeri: birth to 3 months. Polar Biol 30:459-469

Costa DP (1991a) Reproductive and foraging energetics of high latitude penguins, albatross and pinnipeds: implications for life history patterns. Am Zool 31:111-130

Costa DP (1991b) Reproductive and foraging energetics of pinnipeds: implications for life history patterns. In: Renouf D (eds) Behaviour of pinnipeds. Chapman \& Hall, London, p 300-344

Costa DP (1993) The relationship between reproductive and foraging energetics and the evolution of the pinnipedia. In: Boyd I (ed) Marine mammals: advances in behavioural and population biology. Symp Zool Soc Lond 66:293-314

Costa DP, Gales NJ (2000) Foraging energetic and diving behaviour of lactating New Zealand sea lions, Phocarctos hookeri. J Exp Biol 203:3655-3665

> Costa DP, Gales NJ, Crocker DE (1998) Blood volume and diving ability of the New Zealand sea lions, Phocarctos hookeri. Physiol Zool 71:208-213

> Costa DP, Gales NJ, Goebel ME (2001) Aerobic dive limit: How often does it occur in nature? Comp Biochem Physiol 129:771-783

Costa DP, Kuhn CE, Weise MJ, Shaffer SA, Arnould JPY (2004) When does physiology limit the foraging behaviour of freely diving mammals? Int Congr Ser 1275:359-366

Costa DP, Weise MJ, Arnould JPY (2006) Worldwide pinniped population status and trends. In: Estes J, Williams TM, Doak D, DeMaster D (eds) Whales, whaling, and ocean ecosystems. University of California Press, Berkeley

Crocker DE, Gales NJ, Costa DP (2001) Swimming speed and 
foraging strategies of New Zealand sea lions (Phocarctos hookeri). J Zool Lond 254:267-277

Ford JKB, Ellis GM, Barret-Lennard LG, Morton AB, Palm RS, Balcomb KC (1998) Dietary specialization in two sympatric populations of killer whales (Orcinus orca) in coastal British Columbia and adjacent waters. Can J Zool 76: 1456-1471

Fowler SL, Costa DP, Arnould JP, Gales NJ, Kuhn CE (2006) Ontogeny of diving behaviour in the Australian sea lion: trials of adolescence in a late bloomer. J Anim Ecol 75: 358-367

Fowler SL, Costa DP, Arnould JP (2007) Ontogeny of movements and foraging ranges in the Australian sea lion. Mar Mamm Sci 23:598-614

Gales NJ, Mattlin RH (1997) Summer diving behaviour of lactating New Zealand sea lions, Phocarctos hookeri. Can J Zool 75:1695-1706

Gales NJ, Mattlin RH (1998) Fast, safe, field-portable gas anesthesia for pinnipeds. Mar Mamm Sci 14:355-361

Goebel ME (1998) Female foraging behavior: inter- and intraannual variation in individuals. In: Gentry RL (ed) Behavior and ecology of the northern fur seal. Princeton University Press, NJ, p 243-259

Goebel ME, Bengston JL, Delong RL, Gentry RL, Loughlin TR (1991) Diving patterns and foraging locations of female northern fur seals. Fish Bull 89:171-179

Goodman-Lowe GD, Carpenter JR, Atkinson S, Ako H (1999) Nutrient, fatty acid, amino acid and mineral analysis of natural prey of the Hawaiian monk seal, Monachus schauinslandi. Comp Biochem Physiol A 123:137-146

Hindell MA, Slip DJ, Burton H (1991) The diving behaviour of adult male and female southern elephant seals, Mirounga leonine. J Zool Lond 39:595-619

Hitchmough RA, Bull L, Cromarty P (2007) New Zealand Threat Classification Systems list 2002. Department of Conservation, Threatened Species Occasional Publication 23, Wellington

Hooge PN, Eichenlaub WM, Solomon EK (2000) Using GIS to analyse animals movements in the marine environment. Alaska Biological Science Centre, US Geological Survey, Gustavus, AK

Mattlin RH, Scheibling RE, Forch EC (1985) Distribution,

Editorial responsibility: Rory Wilson,

Swansea, UK abundance and size structure of arrow squid (Nototodarus sp.) off New Zealand. NAFO Sci Counc Stud 9:39-45

McCafferty DJ, Boyd IL, Walker TR, Taylor RI (1998) Foraging responses of Antarctic fur seals to changes in the marine environment. Mar Ecol Prog Ser 166:285-299

McConnell BJ, Chambers C, Fedak MA (1992) Foraging ecology of southern elephant seals in relation to the bathymetry and productivity of the Southern Ocean. Antarct Sci 4: 393-398

Miller AK, Sydeman WJ (2004) Rockfish response to lowfrequency ocean climate change as revealed by the diet of a marine bird over multiple time scales. Mar Ecol Prog Ser 281:207-216

Rosen DAS, Trites AW (2000) Digestive efficiency and drymatter digestibility in Steller sea lions fed herring, pollock, squid, and salmon. Can J Zool 78:234-239

Sargeant BL, Mann J, Berggren P, Krutzen M (2005) Specialization and development of beach hunting, a rare foraging behavior, by wild bottlenose dolphins (Tursiops sp.). Can J Zool 83:1400-1410

Seaman DE, Powell RA (1996) An evaluation of the accuracy of kernel density estimators for home range analysis. Ecology 77:2075-2085

Smolker RA, Richards AF, Connor RC, Mann J, Berggren P (1997) Sponge carrying by Indian Ocean bottlenose dolphins: possible tool-use by a delphinid. Ethology 103: $454-465$

Tinker MT, Bentall G, Estes JA (2008) Food limitation leads to behavioral diversification and dietary specilization in sea otters. Proc Natl Acad Sci 105:560-565

Tremblay Y, Cherel Y (2000) Benthic and pelagic dives: a new foraging behaviour in rockhopper penguins. Mar Ecol Prog Ser 204:257-267

> Villegas-Amtmann S, Costa DP, Tremblay Y, Salazar S, Aurioles-Gamboa D (2008) Multiple foraging strategies in a marine apex predator, the Galapagos sea lion Zalophus wollebaeki. Mar Ecol Prog Ser 363:299-309

> Werner R, Campagna C (1995) Diving behaviour of lactating southern sea lions (Otaria flavescens) in Patagonia. Can J Zool 73:1975-1982

> Worton BJ (1989) Kernel methods for estimating the utilization distribution in home range studies. Ecology 70:164-168

Submitted: August 1, 2008; Accepted: November 22, 2008 Proofs received from author(s): March 2, 2009 